\title{
Preparation of the saphenous vein for coronary artery bypass grafting: A new technique - "no touch" - that maintains the vein wall integral and provides high immediate patency
}

\author{
Preparo da veia safena na cirurgia de revascularização miocárdica: uma nova técnica -"no touch"- \\ que mantém a parede da veia íntegra e proporciona uma alta perviabilidade imediata
}

Domingos S. R. SOUZA ${ }^{1}$, Michael R. DASHWOOD ${ }^{2}$, Alan TONAZI ${ }^{3}$, Benny JOHANSSON ${ }^{1}$, Enio BUFFOLO ${ }^{4}$, Ricardo LIMA ${ }^{5}$, Derek FILBEY ${ }^{1}$, Vollmer BOMFIM ${ }^{1}$

RBCCV 44205-650

\section{Abstract}

Background: The technique of harvesting the saphenous vein (SV) for coronary artery bypass grafting (CABG) influences the fate of vein grafts. A new "no touch" (NT) technique of $\mathrm{SV}$ preparation was developed where the vein is harvested with a pedicle of surrounding tissue, which protects the vein from spasms therefore obviating the need for distension.

Method: A prospective randomized study in 156 patients who underwent CABG was performed comparing three SV harvesting techniques. The techniques were conventional (c) (adventitial stripping of the vein, manual distention and storing in saline solution); Intermediate (I) (after adventitial stripping, the vein was left in situ, covered with a papaverinesoaked compress, and stored in heparinized blood); and "no touch" (SV dissected with its surrounding tissue was left in situ, covered with a saline-soaked compress and stored in heparinized blood). A morphological study of the endothelium was preformed using scanning electronic microscopy and an angiographic assessment of the vein graft patency was performed at 18 months mean follow-up time. Also an immunohistochemistry assessment was performed to identify the enzyme, nitric oxide synthase (NOS) in the vein wall.

Results: The preservation of the endothelial cell integrity was greater with the "no touch" technique than with the other procedures. At angiographic follow up, the patency for NT was $95.4 \%, 88.9 \%$ for grafts in group $C$ and $86.2 \%$ for grafts in group I. The immunohistochemistry assessment revealed NOS in all three layers of the vein wall that was prepared by the "no touch" technique. However, a great reduction of this enzyme in veins treated by the conventional technique was observed.

Conclusion: The endothelial integrity and NOS activity were better preserved when using the "no touch" technique for vein graft harvesting. The vasorelaxation and thromboresistant activities of nitric oxide (NO) may be responsible for the reduced of vasospasms and improved patency rate. Furthermore, the mechanical properties provided by the

1 - Cardiothoracic Surgery Division, University Hospital of Örebro, Sweden.

2 - Molecular Pathology and Biochemical Division, University Hospital Royal Free College Medical School, Royal Free Campus, London, UK

3 - Hospital do Servidor Público Estadual, Rio de Janeiro, Brazil 4 - Cardiothoracic Surgery Division, Paulista Medical School UNIFESP, São Paulo, Brazil.

5 - Cardiothoracic Surgery Division, Hospital Oswaldo Cruz, Recife, Brazil.

Correspondence address: Dr Domingos Souza, Dept of Cardiothoracic Surgery, Örebro University Hospital, SE-701 85 Örebro, Sweden.

E-mail: domingos.souza@orebroll.se 
cushion of surrounding tissue in graft harvested by NT technique may contribute to the observed high patency rate.

Descriptors: Saphenous vein. Endothelium, vascular. Myocardial revascularization, methods.

\section{Resumo}

Objetivo: O objetivo deste trabalho é apresentar uma nova técnica "no touch" de preparo da veia safena e sua importância clínica. Esta nova técnica consiste na retirada da veia safena do seu leito, juntamente com um pedículo de tecido adiposo, protegendo a veia contra espasmos e, conseqüentemente, da necessidade de distendê-la durante a operação.

Método: O estudo foi realizado em dois tempos: 1) Inicialmente, foi realizado um estudo prospectivo e randomizado, envolvendo 156 pacientes que foram submetidos à operação de revascularização miocárdica. Neste estudo nós comparamos a técnica "no touch" (NT) com duas outras: a convencional (C) e a intermediária (I). Foi feita uma avaliação detalhada da morfologia endotelial, utilizando a microscopia eletrônica, enquanto que a perviabilidade das pontes foi determinada com um exame angiográfico executado num período médio de 18 meses após a operação. 2) Finalmente, a enzima óxido nítrico síntase (NOS) foi identificada com ajuda do estudo imunohistoquímico e também pela localização

\section{INTRODUCTION}

Coronary arteriosclerotic disease is the most important cause of morbidity and mortality in industrialized countries. More than one million people, around the world, die annually of coronary heart disease [1]. A surgical procedure utilized, the saphenous vein (SV) graft, first seen in the 1960 s, profoundly altered the situation of ischemic heart disease patients, providing them with an excellent quality of life. However, failure of the saphenous graft is associated with the reoccurrence of angina [2], which is one of the main reasons for reoperations. It has been demonstrated that approximately $30 \%$ of the saphenous grafts occlude within the first postoperative year [3] and in 10 years, the occlusion rate can be greater than $50 \%$.

Recently, the use of arterial grafts, which seem to give better long-term results, has become more common. In spite of this, the SV continues to be the most frequently used graft employed in coronary artery bypass grafting (CABG). Consequently, everything must be done, to improve the results of the permeability of saphenous grafts. Preparation of the vein plays a very important role, as there is evidence that surgical manipulation, during its preparation, causes serious morphological and functional injuries. [4]

The main aim of this work is to evaluate the "no touch" auto-radiográfica de (3H)-L- Nitro-Arginina (NOARG).

Resultados: A avaliação morfológica mostrou integridade endotelial de $97 \%$ nas veias que foram tratadas pela técnica NT; enquanto quase metade da superfície endotelial das veias tratadas pelas outras duas técnicas exibiu ausência de células endoteliais. $O$ exame angiográfico revelou perviabilidade de $\mathbf{9 5 , 4} \%$ para as pontes do grupo NT, $88,9 \%$ para as pontes do grupo (C) e $86,2 \%$ para as pontes do grupo (I). O estudo imunohistoquímico revelou a presença de NOS nas três camadas que compõem a parede da veia quando, as mesmas, foram tratadas pela técnica NT. Por outro lado, foi observada uma elevada redução desta enzima nas veias que foram tratadas pela técnica $(C)$. A análise auto-radiográfica confirmou os resultados imunohistoquímicos.

Conclusão: A integridade endotelial e a atividade da enzima óxido nítrico síntase foram melhor mantidas com o uso da técnica NT no preparo da veia safena. A atividade vasodilatadora e bloqueadora da agregação plaquetária causada pelo óxido nítrico (NO) pode ser a responsável pela proteção da veia contra o espasmo, como também pela alta perviabilidade imediata da mesma. Além disso, as propriedades mecânicas providas pelo tecido gorduroso em volta da veia, contribuíram para o melhor resultado desta nova técnica.

Descritores: Veia safena. Endotélio vascular. Revascularização miocárdica, métodos.

technique [5] including its clinical importance, in the preparation of the SV.

\section{METHOD}

\section{Patient Selection}

Following approval of the local Ethics Committee and with informed written consent, 156 patients were submitted to the CABG surgery, in the Cardiothoracic Surgery Division of the University Hospital of Örebro, Sweden. The patients were randomly divided into three groups related to three different techniques for the preparation of the SV. The selected inclusion criteria of the patients aimed at the possibility of the implementation of long-term control. The surgeries were performed between June 1993 and April 1997.

\section{Vein preparation techniques \\ Group C - Conventional technique:}

The SV was exposed by a longitudinal incision. The adventitial layer was stripped and the collateral branches were ligated with 3-0 cotton thread. The vein was removed from its bed immediately after dissection, and was manually distended with saline solution at $300 \mathrm{mmHg}$, during one minute. After dissection, the vein was stored in saline solution at room temperature. 


\section{Group I - Intermediate technique}

The SV was dissected as in Group C. Instead of using manual distention, the vein was submitted to the following procedures: Initially it was left in situ and covered with a compress moistened with saline solution containing papaverine $(1 \mathrm{mg} / \mathrm{mL})$, until starting the perfusion. After its removal, the vein was stocked in blood obtained from the aortic cannula. Despite the use of papaverine, almost all the veins required mechanical distension to overcome spasms.

\section{Group NT - "No touch" technique:}

The VS was also exposed by a continuous incision. All the visible collateral branches were ligated, approximately $0.5 \mathrm{~cm}$ from the vein wall using 3-0 cotton thread. Subsequently, the vein together with a pedicle of fat tissue was isolated from its bed (Figure 1) and left in situ, until starting perfusion, covered with a compress dampened with a pure saline solution. After removal, the vein was stored in blood drawn from the arterial cannula.

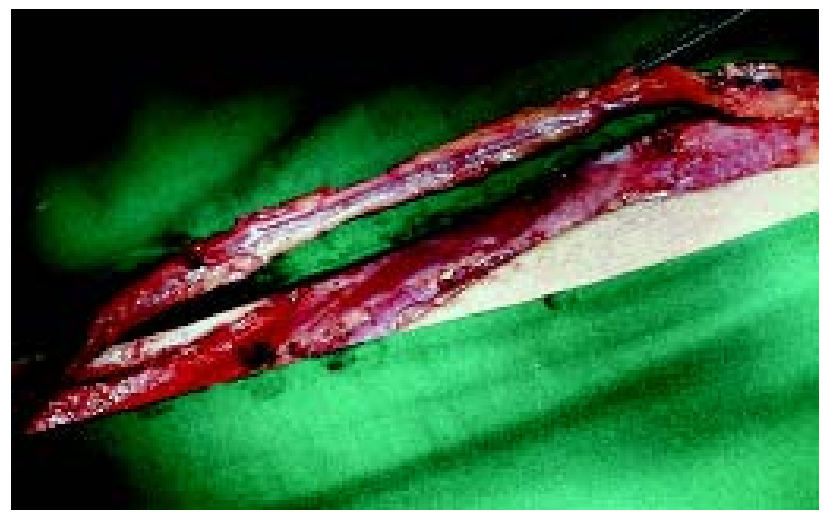

Fig. 1 - Saphenous vein "in situ" together with the pedicle of adipose tissue, after dissection from its bed

In summary the conventionally treated veins were stripped and distended, the intermediately treated veins were stripped but not distended and the vein treated by the "no touch" method were neither stripped nor distended.

\section{Surgical aspects}

Cardiopulmonary bypass and intermittent retrograde cardioplegia at $4{ }^{\circ} \mathrm{C}$ were routinely utilized, as were special probes to measure the diameter of the coronary arteries.

In all the groups, the distal anastomoses were performed first

To verify fortuitous bleeding of the anastomoses or the collateral branches of the vein in the NT and I groups, its proximal end was quickly connected to the arterial cannula of the cardiopulmonary bypass. In group C, the veins were manually tested using a syringe containing saline solution. All the internal mammary arteries (IMA) were anastomosed to the anterior descending coronary artery (AD). The proximal anastomoses were performed after interruption of the aortic clamping. The characteristics of the veins, as well as their qualities and origin (distal, medial and proximal) were taken into consideration and registered. The flow through the grafts was measured using an ultrasound study (Research flow meters, Transonic Systems Inc. USA).

\section{Morphological evaluation}

A morphological examination of the endothelium using electronic microscopy (EM) was performed on vein samples obtained from ten consecutive patients from each group. The control samples were collected from the distal part of the veins, immediately after harvesting. These control samples (or primary samples) were not dilated nor stored, but immediately fixed. After ending the proximal anastomosis, another sample, the secondary sample was obtained from the trimmed segment of the vein and this was also fixed.

Fixing was achieved by immersion of the samples in $2 \%$ paraformaldehyde and 2.5\% glutaraldehyde in Millonig buffer solution.

\section{Immunohistochemical evaluation}

In ten other patients, the proximal part of the vein was prepared with the "no touch" technique, whilst the distal part was prepared by the conventional technique. Both segments were stored in heparinized blood until the moment of distal anastomosis. Samples of the surplus vein were obtained after performing the proximal anastomosis, and the control samples were taken from the stripped veins that had not been dilated.

The classical immunohistochemical method was used to identify endothelium cells and collagen. The vein samples were fixed in acetone and the activity of the endogen enzymes was inhibited with normal goat serum, in order to block alterations in the coloring. Following this the tissue was incubated, both with CD31 antibodies to identify the endothelium cells, and with rat monoclonal antibodies, to identify the collagen. A solution of 3,3'-diaminobenzidin tetrachloride was employed as a substrate and the sections were stained with Mayer hematoxylin and prepared for microscopic examination. An examination using NADPHdiaphoresis (Sigma-Aldrich, Poole, Dorset, UK) was used to locate the enzyme nitric oxide synthase (NOS), which is a precursor of nitric oxide.

An "in vitro" auto-radiograph using nitroarginine (NOARG) marked with an isotopic substance was utilized to locate the NOS sites in the endothelium. The slides were pre-incubated in a HCL buffer solution and, subsequently, incubated in a solution containing $10 \mathrm{nM}$ of radioactive NOARG. After incubation, they were rinsed and air-dried. The slides initially were post-fixed in paraformaldehyde, after dipped in a nuclear emulsion and then dried over night. 
Finally, they were placed in lightproof boxes and stored at $4^{\circ} \mathrm{C}$ for 12 weeks. After this procedure, the tissue was prepared with Mayer hematoxylin-eosin solution and examined using a microscope under an illumination with dark and bright fields-of-view.

This study was performed in this manner to avoid possible suspicion that we had chosen the best quality veins for treatment by the "no touch" method. Our intention here was to verify the immunohistochemical effect on two segments of the same vessel, which had been treated by two different techniques.

\section{Angiographic evaluation}

Approximately 18 months after the operation, an angiographic control was performed, according to the technique of Judkins [6]. Vispaque, a substance of low osmolarity, was used as contrast (Nycomed Amersham AB, Stockholm). The angiographic evaluation was executed at random by two radiologists. The grafts were visualized from two projections and the patency rate and the degree of localized and diffused lesions were determined. Occlusion was determined by the identification of a remaining neck of the graft after a selective injection of contrast inside the proximal anastomosis and by the lack of opacification of the grafts after the injection of 50 $\mathrm{mL}$ of contrast in the ascending aorta.

\section{Statistical methods}

The non-matched Kruskal-Wallis test was used in a retrospective analysis to enable a morphological comparison of the endothelium among the three groups, as described by SIEGEL \& CASTELLAN [7].

The patency of the grafts was assessed with the logic regression model. The main explanatory factor was the three different techniques to prepare the veins: conventional, intermediate and "no touch". Additional factors were individually examined. Those that presented with a significant association in the results and that had an irregular distribution throughout the different preparation techniques were selected and used in the final model.

\section{RESULTS}

\section{Characteristics of the patients}

Among the groups, no significant difference in the characteristics of the patients was found (Table 1). Those who were using medicine against the high lipid levels or who revealed a level of cholesterol above the normal (2.6 $5.0 \mu \mathrm{mol} / \mathrm{L}$ ) were considered to have hyperlipidemia. In respect to the arterial pressure, hypertension was defined as a diastolic pressure above $90 \mathrm{mmHg}$ or a systolic pressure greater than $140 \mathrm{mmHg}$. The left ventricular function was determined by the ejection fraction (EF).
Table 1. Characteristics of the patients. Operational technique

\begin{tabular}{|c|c|c|c|}
\hline Characteristics of the patients & Conventional & Intermediate & "No-touch" \\
\hline Number of patients (n) & 46 & 41 & 45 \\
\hline Female/male & $6 / 40$ & $8 / 33$ & $7 / 38$ \\
\hline \multicolumn{4}{|l|}{ Age at operation } \\
\hline Mean (Range) & $58(45-70)$ & $60(41-71)$ & $58(43-67)$ \\
\hline Pre-operative infarction ( $\mathrm{n} \%$ ) & $29(63 \%)$ & $16(39 \%)$ & $25(56 \%)$ \\
\hline \multicolumn{4}{|l|}{$\begin{array}{l}\text { Pre-operative } \\
\text { ejection fraction }\end{array}$} \\
\hline Mean (Range) & $63(41-81)$ & $67(39-87)$ & $67(40-86)$ \\
\hline \multicolumn{4}{|l|}{ Hyperlipidemia, (n \%) } \\
\hline Pre-operative & $29(63 \%)$ & $19(46 \%)$ & $29(64 \%)$ \\
\hline 18 months after operation & $22(48 \%)$ & $20(49 \%)$ & $27(60 \%)$ \\
\hline \multicolumn{4}{|l|}{ Smokers (n \%) } \\
\hline Pre-operative & $9(20 \%)$ & $4(10 \%)$ & $9(20 \%)$ \\
\hline 18 months after operation & $9(20 \%)$ & $1(2 \%)$ & $6(13 \%)$ \\
\hline
\end{tabular}

Use of aspirin was indicated on the first post-operative day with a dose of $160 \mathrm{mg}$ daily. During the period of the angiographic examination, 42 patients in group $C$ were taking a dose of $160 \mathrm{mg} /$ day, 3 were taking $75 \mathrm{mg} /$ day and 1 patient was not taking any antiplatelet agents. In group I, 35 patients were receiving $160 \mathrm{mg} /$ day, 4 were receiving $75 \mathrm{mg} /$ day and 2 were not taking any antiplatelet drugs. In the NT group, 35 were taking $160 \mathrm{mg}$ /day, 7 patients were taking $75 \mathrm{mg} /$ day and 3 were not receiving any antiplatelet agents.

\section{Morphologic findings}

The secondary samples of the NT group exhibited cellular integrity similar to the control samples. However, almost a half of the endothelial surfaces of the samples in group C presented with a significant absence of endothelial cells, whilst the samples in group I exhibited endothelial integrity between Group C and Group NT.

Comparing the samples of the three groups, we evidenced a significant difference in the endothelial integrity, with results that revealed the following p-values: control versus conventional sample P-value $<0.01$; control versus intermediate sample p-value $<0.05$ and control versus "no touch" sample $p$-value $>0.05$. Figures 2 and 3 demonstrate the degree of endothelial injury in a vein sample of the "no touch" Group and in a vein sample of the conventional Group.

\section{Immunohistochemical findings}

The immunohistochemical study, for the identification of collagen fibers, demonstrated an intact adventitial layer containing micro-vessels in the Group NT veins. It was absent in the SVs prepared by the conventional technique (Figure 4). 


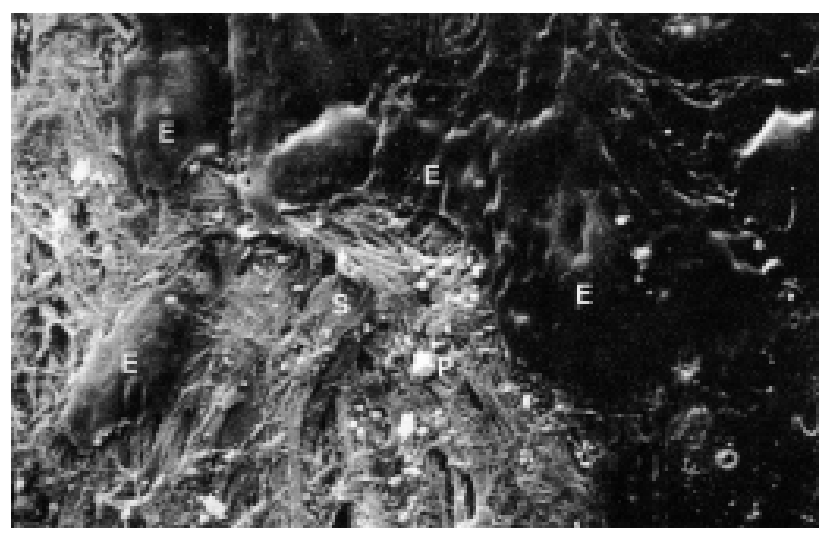

Fig. 2 - Electronic microscopy of a vein prepared by the conventional technique. The endothelial layer is observed by the: loss of endothelial cells (E); exposure of the subendothelial connective tissue $(\mathrm{S})$; adhesion and activation of the platelets $(\mathrm{P})$ and deposition of fibrin (arrow). bar $=50 \mu \mathrm{m}$

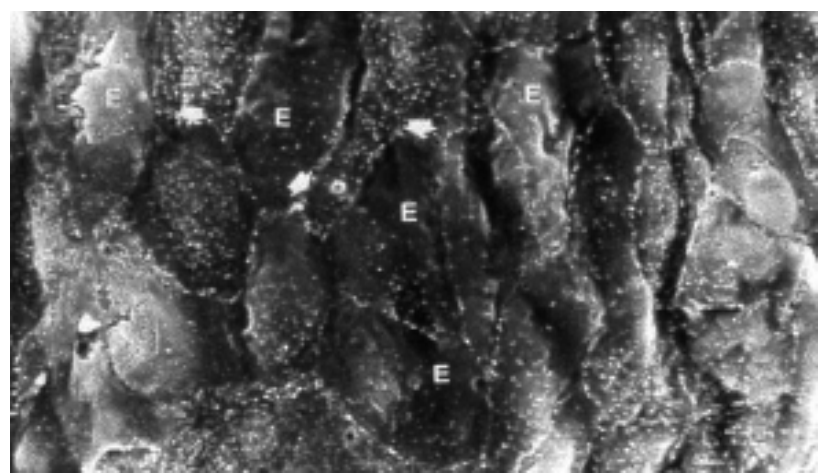

Fig. 3 - Electronic microscopy of the "no touch" vein. The endothelium is intact and the endothelial cells (E) exhibit prominent borders (bar) and micro-villosities, indicating that the metabolic activity was also preserved at the moment of fixation

NOS was identified by the auto-radiographic study, incubating tissue in a solution containing marked NOARG. We noted that there is a direct dependence between the binding of NOARG in the lumen of the vessels and the proportion of the area of endothelium that was intact, which revealed that the veins in Group NT were normal. However, the binding was reduced in the veins of Group C (Figure 5).

Analysis made with NADPH - diaphoresis revealed a reduction of $19.5 \%$ NOS in veins of Group I (control), that is, the veins were stripped, but not dilated, when compared with veins from the Group NT. The reduction was much greater for the veins from Group C, with a rate as high as $35.5 \%$.

\section{Surgical findings}

The mean duration of CPB and aortic clamping time were 121 (from 59 to 187) minutes and 64 (from 34 to 95) minutes, respectively in Group C; 126 (from 90 to 180) and 69 (41-117) respectively for Group I and 139 (88-195) and 72 (41-113) respectively for Group NT. The majority of the patients of all three groups received three saphenous grafts (SG) and one IMA graft.

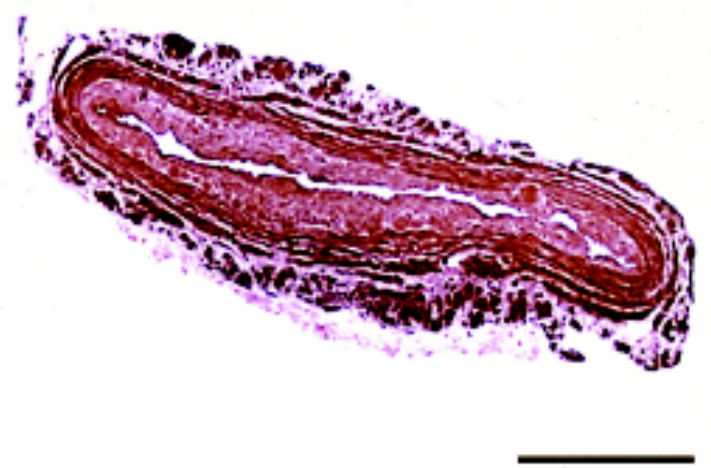

\section{a Convencional}

i

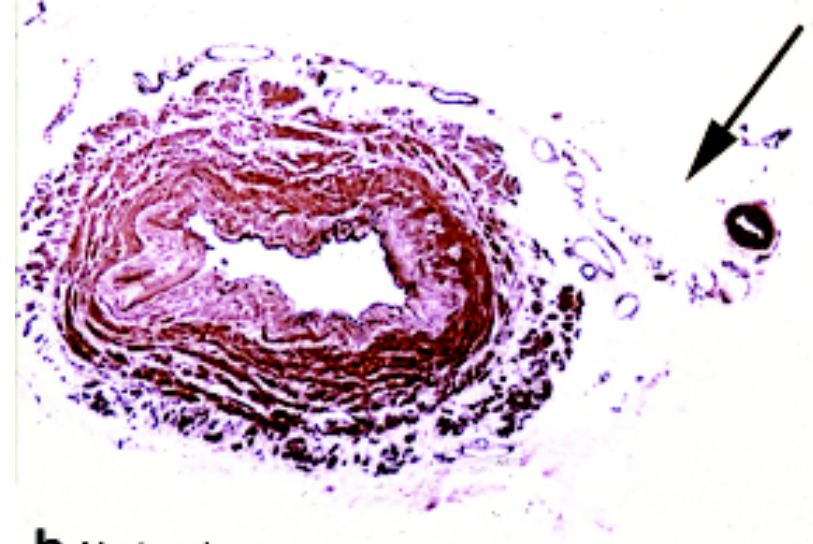

b No-touch

Fig. 4 - Contents of the collagen at the point of the saphenous vein Cross cut of the vein prepared by the: conventional and "no touch" methods. The preparation of the sample was made with rat monoclonal antibodies, anticollagen IV. Observe the accentuated coloring of the adventitial layer of the "no touch" vein (absent in the conventional sample) with abundance of micro-vessels (arrow). Bar $=250 \mu \mathrm{m}$

A total of 127 SG and 41 IMA grafts were implanted in Group C. In Group I, 116 SG and 35 IMA grafts were used and in Group NT a total of 124 SG and 42 IMA grafts were utilized. In Group C the number of 107 simple, 16 double sequential and 4 triple sequential grafts were used. In Group I, 100 simple, 14 double sequential and 2 triple sequential grafts were employed and in Group NT, 109 simple and 15 double sequential grafts were used. The mammary artery was not considered to be suitable for use in 5 patients of Group C, 5 in Group I and 3 in Group NT. Thromboendarterectomy (TEA) was performed in 2 posterior 

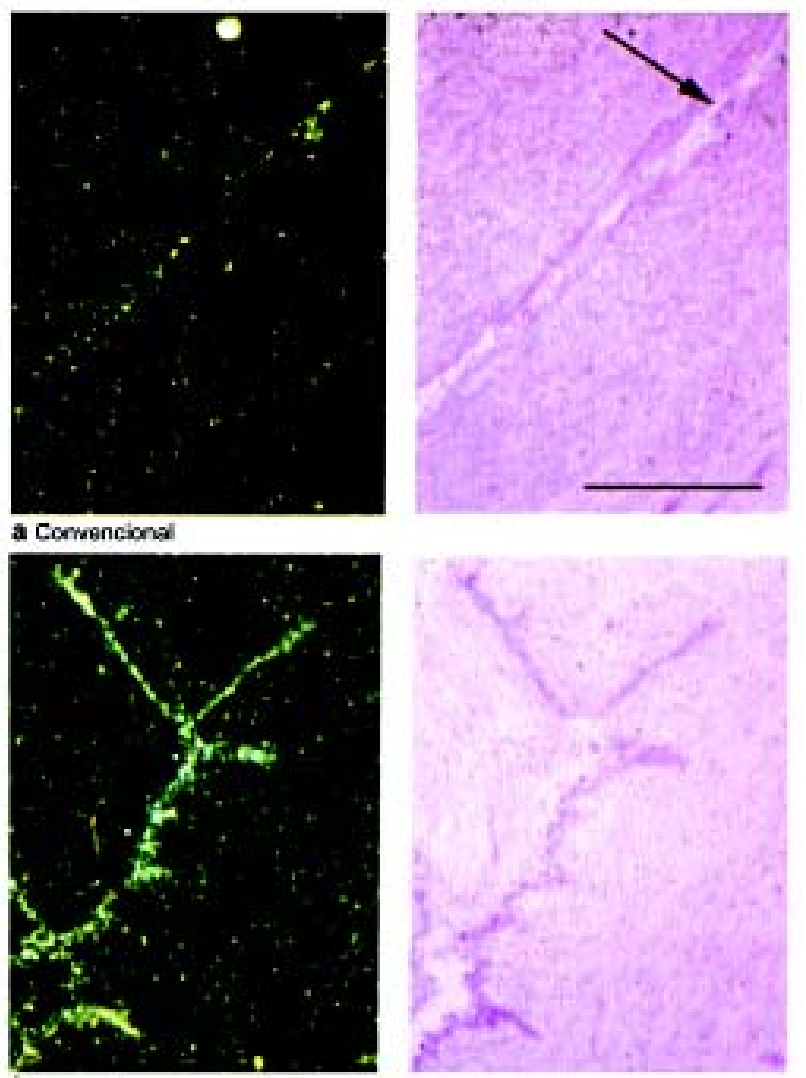

Fig. 5 - The nitroarginine binding to a) conventionally prepared vein, b) vein prepared by the "no touch" technique. NOS was identified by "in vitro" self-radiography. Binding is demonstrated in the panel to the left as white granules under dark field illumination. The panels to the right are tissues stained with hematoxylin-eosin. The endothelium remains in the "no touch" veins (b), while only a few endothelial cells remain intact in the conventionally prepared veins

descending coronary arteries (PD) in Group $\mathrm{C}$, and in one of Group I. However no TEA was necessary in Group NT.

The per-operative mortality rate was $0 \%$ in the three groups. Per-operative myocardial infarction occurred in 2 patients of Group C. One patient of Group NT was re-operated due to bleeding of the bed of the left internal mammary artery. Mild complications associated with the leg wound, such as superficial infections and cellulitis were evidenced in approximately $10 \%$ of the patients of each group.

\section{Patency of the grafts}

One hundred and thirty-two patients were submitted to an angiographic control examination, 46 from Group C, 41 from Group I and 45 from Group NT. Six patients of Group C, 11 from Group I and 7 from Group NT refused to undertake the examination. The mean angiographic follow-up time was
$17.2 \pm 4.4$ months for Group C, $16 \pm 2.6$ months for Group I and $16.3 \pm 2.7$ for Group NT.

The patency of the SGs in Groups NT, C and I were 118/ $124(95.4 \%), 113 / 127(88.9 \%)$ and $100 / 116(86.2 \%)$ respectively. The patency of the IMA grafts was $108 / 118$ (91.5\%).

The grafts that had low flow and that were simultaneously anastomised to small caliber veins had a high incidence of occlusion in the three groups. The quality of the coronary arteries did not influence the patency of the grafts in any of the groups. Both the grafts in Group $\mathrm{C}$ that were anastomised to posterior descending arteries, after TEA, functioned well. The occlusion rates of the low-quality veins were 4/10 (44.4\%) in Group C, 6/19 (31.6\%) in Group I and 3/ $29(10.3 \%)$ in Group NT.

All the sequential grafts in Groups NT and I functioned adequately. However, two sequential grafts were totally occluded and two others partially in Group C. Thus 47/51 $(92.2 \%)$ of all the sequential grafts were completely open.

Statistical analysis by logistic regression of the most important factors that effect the results of the patency rate of the grafts gave a better statistical difference for Group NT compared with Group C (p-value $=0.025)$. The worst result was found in Group I (Table 2).

Between the occlusion of the grafts and the classical clinical factors that can influence their results, such as age, pre-operative myocardial infarction, the level of cholesterol, smoking and arterial hypertension, no associations were found.

Figure 6 demonstrates a "no touch" graft which was anastomosed to a 1-mm coronary artery. When the vein is protected by a pedicle of fat tissue, kinking of the graft does not occur (Figure 7).

\section{COMMENTS}

For several reasons, the SV and the IMA continue to by very important in CABG surgery. Accomplishment of the best result in the patency of the SGs is a great challenge in cardiovascular surgery. The indiscriminate use of arterial grafts utilizing the mammary artery, together with other arterial grafts, until now can not be justified founded on scientific proof as there has been no control study [8].

Different structural and function properties between arteries and veins can probably explain the better results of the arterial grafts [9]. However, injury to the saphenous vein wall, which occurs during its preparation for use as a saphenous graft, might contribute to the poor results of the venous graft. The endothelium of the mammary artery is protected during all the operation. The endothelium of the $\mathrm{SV}$, on the other hand, suffers great lesions during the procedure, making it thrombogenic [10]. Proliferation of the 
the vein wall integral and provides high immediate patency

Table 2. Patency of the simple grafts in the three groups analyzed with the logic regression model with and without support of additional explanatory factors as well as the vein preparation technique ${ }^{\mathrm{a}}$.

\begin{tabular}{|c|c|c|c|c|c|c|c|}
\hline & & & \multicolumn{2}{|c|}{ without adjustment ${ }^{\mathrm{b}}$} & \multicolumn{3}{|c|}{ multivariate adjustment $^{\mathrm{c}}$} \\
\hline & $\begin{array}{l}\text { No of patent } \\
\text { grafts / Total }\end{array}$ & $\begin{array}{l}\text { Odds } \\
\text { ratio }\end{array}$ & $95 \% \mathrm{CI}$ & p- value ${ }^{d}$ & $\begin{array}{l}\text { Odds } \\
\text { ratio }\end{array}$ & $95 \%$ CI & p- value ${ }^{d}$ \\
\hline \multicolumn{8}{|l|}{ Technique } \\
\hline Conventional (reference) & $95 / 107$ & 1.0 & - & - & 1.0 & - & - \\
\hline Intermediate & $84 / 100$ & 0.7 & $0.3-1.6$ & 0.353 & 0.9 & $0.3-2.2$ & 0.745 \\
\hline "No-touch" & $103 / 109$ & 2.2 & $0.7-6.3$ & 0.153 & 3.9 & $1.2-12.6$ & 0.025 \\
\hline \multicolumn{8}{|c|}{ Coronary artery diameter $(\mathrm{mm})$} \\
\hline $1.0 \quad$ (reference) & $21 / 31$ & 1.0 & - & - & 1.0 & - & - \\
\hline 1.5 & $162 / 181$ & 4.1 & $1.7-9.9$ & 0.002 & 3.2 & $1.2-8.3$ & 0.016 \\
\hline$\geq 2.0$ & $99 / 104$ & 9.4 & $3.1-29.1$ & $<0.001$ & 4.7 & $1.4-15.4$ & 0.011 \\
\hline \multicolumn{8}{|l|}{ Flow through graft $(\mathrm{mL} / \mathrm{min})$} \\
\hline$\leq 20 \quad($ reference $)$ & $48 / 64$ & 1.0 & - & - & 1.0 & - & - \\
\hline $21-40$ & $87 / 98$ & 2.6 & $1.1-6.4$ & 0.031 & 1.6 & $0.6-3.8$ & 0.336 \\
\hline$\geq 41$ & $147 / 154$ & 7.0 & $2.9-17.1$ & $<0.001$ & 4.9 & $1.8-13.4$ & 0.002 \\
\hline \multicolumn{8}{|l|}{ Vein quality } \\
\hline Good (reference) & $236 / 257$ & 1.0 & - & - & 1.0 & - & - \\
\hline Poor & $46 / 59$ & 0.3 & $0.1-0.7$ & 0.003 & 0.2 & $0.1-0.6$ & 0.001 \\
\hline \multicolumn{8}{|l|}{ Segment of vein } \\
\hline Distal (reference) & $92 / 96$ & 1.0 & - & - & 1.0 & - & - \\
\hline Medial & $103 / 123$ & 0.2 & $0.1-0.7$ & 0.007 & 0.2 & $0.1-0.8$ & 0.019 \\
\hline Proximal & $87 / 97$ & 0.4 & $0.1-1.3$ & 0.120 & 0.2 & $0.1-0.9$ & 0.040 \\
\hline
\end{tabular}

${ }^{a}$ The parameters are Odds ratio supplemented with the confidence interval of $95 \%$ (Odds ratio greater than 1.0 indicates greater probability of patency compared to the reference category, below 1.0 indicates less probability. The mean time of the angiographies was 18 months.

${ }^{\mathrm{b}}$ No other variable in the model unless the factor individually analyzed.

${ }^{c}$ All the variables in the table were analyzed simultaneously.

d The $\mathrm{p}$-value for the test if the Odds ratio is equal to 1, i.e. no effect compared with the reference category.

$\mathrm{CI}=$ Confidence interval

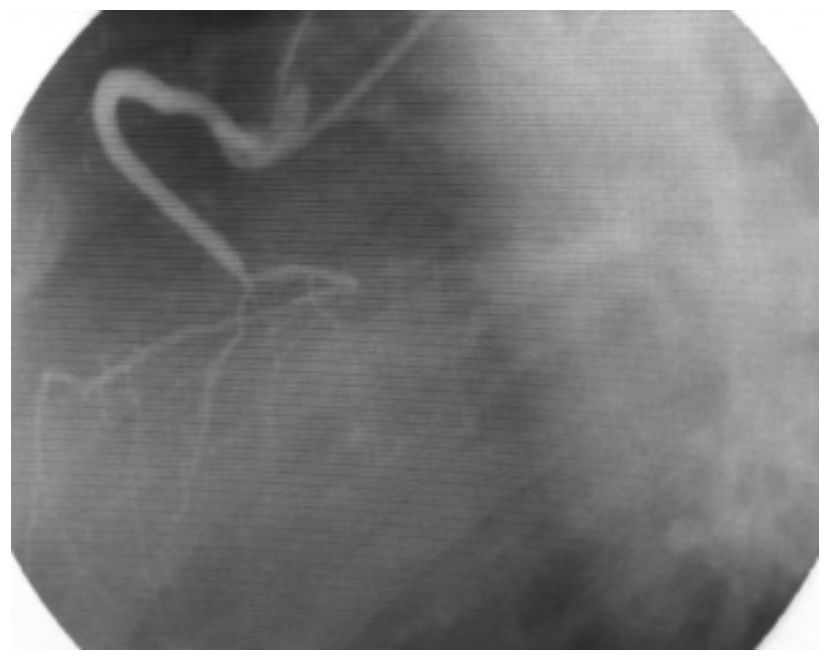

Fig. 6 - A "no touch" saphenous graft anastomised to a 1-mm diameter coronary artery

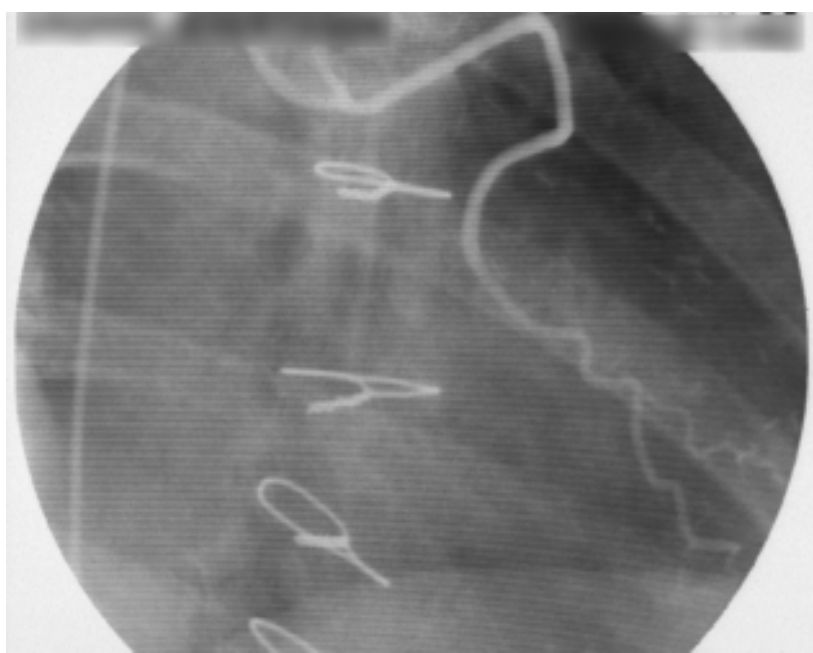

Fig. 7 - An excessively long "no touch" saphenous graft without elbowing 
smooth muscle of the tunica media is similar in uninjured SV and the internal mammary [11]. However, proliferation becomes very accentuated in the veins that suffer endothelial lesion during the operation. This demonstrates that the greatest cause of hyperplasia of the intima layer, detected in saphenous vein grafts, may originate, not from the intrinsic differences of the smooth muscle between arteries and veins, but from the great sensitivity of the vein to trauma.

Many strategies have been used to prevent occlusion of the veins. Apart from established medicinal therapy, new pharmacological agents [12] and genetic therapy [13] are constantly being evaluated. Nevertheless, an important aspect is the continual improvement of the surgical techniques to prevent lesion of the vein walls during the operation.

Removal of the SV, together with a pedicle of tissue around it, protects the vein from spasms and, consequently, avoids the necessity of distending it. Furthermore, the pedicle enables meticulous manipulation of the vein, from its removal to the moment of implantation.

The "no touch" technique demonstrated excellent maintenance of the endothelial integrity, which was confirmed by electronic microscopy [14]. The fat pedicle contains a great amount of collagenous fibers, which might offer an external protection of the vein wall against the deleterious effect of the aortic pressure. The alterations in the distribution of NOS in SVs prepared by the "no touch" technique were compared with veins treated by the conventional technique [15]. We observed that in the veins of the "no touch" group, the preservation of this enzyme occurred in the endothelial, tunica media and adventitial layers. The quantity of NOS was reduced both with the removal of the tissue adjacent to the vessel and by distention, thus suggesting that these measures contribute to a reduction of the quantity of NOS in veins prepared using the conventional technique. Distention seems to have a great effect in the reduction of the amount of NOS, both in the endothelial and tunica media, whilst stripping of the perivascular tissue removes important sources of NOS of the adventitial layer. Preservation of the NOS indicates that the amount of available nitric oxide (NO), usually reduced in conventionally prepared veins [16], might be much higher in veins prepared using the "no touch" technique. This might also be one of the main reasons for the improved result of the SV prepared by this new technique.

The early patency rate of the SV prepared by the "no touch" technique was very high (95.4\%), even in grafts which had low flows [17]. To investigate if the pedicle of fat has importance in the improved patency of the saphenous grafts, we compared the angiographic results between the grafts from the "no touch" group with those treated by the conventional and intermediate techniques. The results demonstrated that the patency was better established when the "no touch" technique was used ( $p$-value $=0.02$ ).

When the vein is stripped of its surrounding tissue, adjustment of the graft length must be very accurate, so as not to run the risk of kinking and, consequently, functional compromise. Many techniques have been recommended to impede this type of complication [18], and this can easily be avoided if the saphenous vein is separated in its bed together with a pedicle of adipose tissue.

\section{CONCLUSION}

The endothelium integrity was better maintained using the "no touch" technique. The adventitial layer and the other structures contained in the fat tissue possess mechanical and functional properties that protect the vein from spasm and ischemia. The activity of the precursor enzyme of nitric oxide, NOS, in the endothelium and also in the neurons and micro-vessels in the adventitial layer, suggests that the availability of nitric oxide is maintained in the grafts treated by the "no touch" technique. Thus, the nitric oxide can be considered as the factor responsible for the improvement of the early patency of the grafts in the "no touch" group. Additionally, the surrounding tissue protects grafts that are excessively long, against the development of kinking.

\section{ACKNOWLEDGEMENTS}

We, the authors, wish to express our thanks to all that collaborated on the execution of this work. Thanks to Eva Norgren Holst, Jane Strand, Laila Örtensö and Margaretha Sandin for their excellent technical assistance; to the nurses of the Surgical Center and Radiology Department, for the specialist help they gave us; and to Dr. Benedicto Ramos de Souza and Dr Maria Inês Cordeiro Guimarães for the linguistic correction. This study had financial support from the University Hospital of Örebro, Sweden. And finally, statistical support was provided by Prof. Lennart Bodin, from the Biostatistics Department of the University Hospital of Örebro.

\section{BIBLIOGRAPHIC REFERENCES}

1. Eisenberg MS. The problem of sudden cardiac death. In: Eisenberg MS, Hallstrom AP, eds. Sudden cardiac death in the community. New York: Praeger; 1984. p.2.

2. Campeau L, Enjalbert M, Lesperance J, Vaislic C, Grondin CM, Bourassa MG. Atherosclerosis and late closure of aortocoronary saphenous vein grafts: sequential angiographic studies at 2 weeks, 1 year, 5 to 7 years, and 10 to 12 years after surgery. Circulation 1983; 68 (3 pt 2): II1-7. 
3. Izzat MB, West RR, Bryan AJ, Angelini GD. Coronary artery bypass surgery: current practice in the United Kingdom. $\mathrm{Br}$ Heart J 1994; 71:382-5.

4. Mills NL, Everson CT. Vein graft failure. Curr Opin Cardiol $1995 ; 10: 562-8$

5. Souza D. A new no-touch preparation technique. Scand J Thorac Cardiovasc Surg 1996; 30:41-4.

6. Judkins MP. Selective coronary arteriography. A percutaneous transfemoral technic. Radiology 1967; 89:815-24.

7. Siegal S, Castellan NJ. Non-parametric statistics for the behavioral sciences. London: McGraw-Hill; 1988.

8. Cooper GJ, Underwood MJ, Deverall PB. Arterial and venous conduits for coronary artery bypass: a current review. Eur J Cardiothorac Surg 1996; 0:129-40.

9. Cox JL, Chiasson DA, Gotlieb AI. Stranger in a strange land: the pathogenesis of saphenous vein graft stenosis with emphasis on structural and functional differences between veins and arteries. Prog Cardiovasc Dis 1991; 34:45-68.

10. Lehmann KH, von Segesser L, Muller-Glauser W, Siebenmann $\mathrm{R}$, Schneider K, Luscher TF, et al. Internal-mammary coronary artery grafts: is their superiority also due to a basically intact endothelium? Thorac Cardiovasc Surg 1989; 37:187-9.

11. Holt CM, Francis SE, Newby AC, Rogers S, Gadsdon PA, Taylor T, et al. Comparison of response to injury in organ culture of human saphenous vein and internal mammary artery. Ann Thorac Surg 1993; 55:1522-8.
12. Sogo N, Campanella C, Webb DJ, Megson IL. S-nitrosothiols cause prolonged, nitric oxide-mediated relaxation in human saphenous vein and internal mammary artery: therapeutic potential in bypass surgery. Br J Pharmacol 2000; 131:1236-44.

13. Shears 2nd LL, Kibbe MR, Murdock AD, Billiar TR, Lizonova A, Kovesdi I, et al. Efficient inhibition of intimal hyperplasia by adenovirus-mediated inducible nitric oxide synthase gene transfer to rats and pigs in vivo. J Am Coll Surg 1998; 187:295-306.

14. Souza DSR, Christofferson RHB, Bomfim V, Filbey D. "Notouch" technique by using saphenous vein harvested with its surrounding tissue for coronary artery bypass grafting maintains an intact endothelium. Scand J Thorac Cardiovasc Surg 1999; 33:323-9.

15. Tsui JCS, Souza DSR, Filbey D, Karlsson MG, Dashwood MR. Localization of nitric oxide synthase in saphenous vein grafts harvested with a novel "no-touch" technique: potential role of nitric oxide contribution to improved early graft patency rates. J Vasc Surg 2002; 35:356-62.

16. Angelini GD, Christie MI, Bryan AJ, Lewis MJ. Surgical preparation impairs release of endothelium-derived relaxing factor from human saphenous vein. Ann Thorac Surg 1989; 48:417-20.

17. Souza DSR, Bomfim V, Skoglund H, Dashwood MR, Borowiec JW, Bodin L, Filbey D. High early patency of saphenous vein graft for coronary artery bypass harvested with surrounding tissue. Ann Thorac Surg 2001; 71:797-800.

18. Durrani A, Sim EK, Grignani RT. Accurate length adjustment of aortocoronary saphenous vein bypass grafts. Ann Thorac Surg 1998; 66:966-7. 